\title{
Prodigiosin Induces Autolysins in Actively Grown Bacillus subtilis Cells
}

\author{
Tjaša Danevčič ${ }^{1}$, Maja Borić Vezjak¹, Maja Tabor ${ }^{1}$, Maša Zorec $^{2}$ and David Stopar ${ }^{1 *}$ \\ ' Chair of Microbiology, Department of Food Science and Technology, Biotechnical Faculty, University of Ljubljana, Ljubljana, \\ Slovenia, ${ }^{2}$ Chair of Microbiology and Microbial Biotechnology, Department of Animal Science, Biotechnical Faculty, \\ University of Ljubljana, Ljubljana, Slovenia
}

\section{OPEN ACCESS}

Edited by:

Enrica Pessione,

University of Turin, Italy

Reviewed by:

Sylvie Garneau-Tsodikova,

University of Michigan, USA

Paul Richard Himes,

University of Louisville, USA

*Correspondence:

David Stopar

david.stopar@bf.uni-lj.si

Specialty section:

This article was submitted to

Systems Microbiology,

a section of the journal

Frontiers in Microbiology

Received: 28 August 2015 Accepted: 11 January 2016 Published: 28 January 2016

Citation:

Danevčič T, Borić Vezjak M, Tabor M, Zorec M and Stopar D (2016) Prodigiosin Induces Autolysins in Actively Grown Bacillus subtilis

Cells. Front. Microbiol. 7:27. doi: 10.3389/fmicb.2016.00027
Prodigiosin produced by marine bacterium Vibrio ruber DSM 14379 exhibits a potent antimicrobial activity against a broad range of Gram positive and Gram negative bacteria. The mechanism of prodigiosin antimicrobial action, however, is not known. In this work, the effect of prodigiosin on Bacillus subtilis growth, cell membrane leakage, and induction of autolysins was studied. Treating $B$. subtilis with prodigiosin resulted in rapid decline of optical density and increased cell membrane leakage measured by $\beta$-galactosidase activity. Cell lysis was initiated immediately after treatment with prodigiosin in the middle exponential phase and was completed within $2 \mathrm{~h}$. Lytic activity of prodigiosin in mutant strains with impaired autolysin genes lyt $A B C D$ decreased for $80 \%$ compared to the wild type strain, while in lytABCDEF mutant strain prodigiosin had no bacteriolytic but only bacteriostatic effect. Fast prodigiosin Iytic activity on individual B. subtilis cells was confirmed by a modified comet assay. The results indicate that prodigiosin autolysin induction in $B$. subtilis is growth phase dependent.

Keywords: prodigiosin, autolysis, Bacillus subtilis, antimicrobial, mechanism, autolysin, lytic rate, comet assay

\section{INTRODUCTION}

Prodigiosin, a secondary metabolite, is produced by several bacterial genera including Serratia, Streptomyces, Vibrio, Hahella, Zooshikella, and Pseudoalteromonas (Farmer et al., 1988; Sawabe et al., 1998; Shieh et al., 2003; Williamson et al., 2006; Kumar and Nair, 2007; Fehér et al., 2010; Starič et al., 2010; Lee et al., 2011; Stankovic et al., 2012). Prodigiosin provides numerous ecophysiological benefits for the producing cell and has a good potential for biotechnological as well as medical applications (Burger and Bennett, 1985; Hood et al., 1992; Ryazantseva et al., 1995; Seganish and Davis, 2005; Haddix et al., 2008; Starič et al., 2010; Borić et al., 2011). Prodigiosin has been used in control of plant diseases caused by bacteria and fungi (Okamoto et al., 1998; Someya et al., 2001; Meschke et al., 2012). It has affinity to DNA (Melvin et al., 2000), but shows no in vitro or in vivo genotoxic effect on Salmonella typhimurium cells (Guryanov et al., 2013). It modulates $\mathrm{H}^{+} / \mathrm{Cl}^{-}$symport activity (Konno et al., 1998). When used as a coloring agent, it retains its antibiotic activity (Alihosseini et al., 2008). Prodigiosin has anticancer, antimalarial and immunosuppressant properties (Pérez-Tomás et al., 2003; Williamson et al., 2007). It inhibits growth of a wide range of Gram positive bacteria including Bacillus subtilis and Staphylococcus aureus, as well as Gram negative Escherichia coli, Salmonella enterica, and Erwinia carotovora (reviewed in Stankovic et al., 2014). The mechanism of its antibacterial action, however, is not understood on the molecular level. In this work, we study the molecular targets of prodigiosin in B. subtilis. 
Many antibacterial agents target cell membrane and cell wall (Falk et al., 2010; Lacriola et al., 2013). In B. subtilis induction of autolysins and subsequent cell wall degradation is a major mechanism of antimicrobial action of several different compounds (Falk et al., 2010; Lacriola et al., 2013). Autolysins are enzymes involved in hydrolysis and remodeling of the peptidoglycan in the bacterial cell wall (Smith et al., 2000). It is absolutely critical to maintain the regulation of potentially suicidal activity of autolysins. The regulation of autolysin activity is mainly due to the local $\mathrm{pH}$ in respiring cells. In respiring cells, protons are extruded across the cytoplasmic membrane and bind to cell wall constituents (Jolliffe et al., 1981; Kemper et al., 1993; Calamita and Doyle, 2002). The protonation of the cell wall constituents create a wall matrix of low $\mathrm{pH}$. Proton motive force sustains this local low $\mathrm{pH}$ and, in turn, autolytic activity is inhibited because $N$-acetylmuramyl-L-alanine amidase cannot function below $\mathrm{pH}$ 5.5. There are 36 autolysins present in the B. subtilis genome (Smith et al., 2000). Among different autolysins in B. subtilis, two autolysins of vegetative growth named LytC and LytD are responsible for about 95\% of the bacterial cell autolysis during active growth (reviewed in Smith et al., 2000). It has been shown previously that $\beta$-galactosidase release correlates with activation of pathways leading to autolysis (Falk et al., 2007). Apart from $\beta$-galactosidase release several other methods (e.g., optical density, cell count) can be used to determine bacterial cell lysis. The comet assay is a method primarily used for the detection of DNA damage and cell lysis in a single cell (Ostling and Johanson, 1984; Singh et al., 1988). Recently, comet assay was applied to detect bacterial lysis after bacteriophage treatment (Khairnar et al., 2014). Using comet assay to detect single cell lysis provides an advantage over enzyme activity or optical density measurements of cell lysis which probe a population response.

In this work, the mechanism of antibacterial activity of prodigiosin on B. subtilis was studied. The ability of prodigiosin to affect bacterial population structure was determined in simple co-culture experiments. The effect of prodigiosin on the bacterial growth, cell wall integrity, autolysis, and DNA damage was determined on the wild type strain and several autolysin mutants. This study is the first attempt to determine the mechanism of antibacterial activity of prodigiosin in B. subtilis in vivo. The results indicate that prodigiosin activates rapid autolysis in B. subtilis.

\section{MATERIALS AND METHODS}

\section{Bacterial Strains, Mutant Strain Construction and Growth Conditions}

Bacterial strains used in this study were $B$. amyloliquefaciens FZB42, B. licheniformis ATCC9445A, B. subtilis NCIB3610 all obtained from BGSC, B. subtilis ATCC6051, B. mycoides DSM2048 obtained from DSMZ, B. subtilis PS-216 wt (Stefanic and Mandic-Mulec, 2009), B. subtilis PS-216 amyE:: $\mathrm{P}_{\text {hyperspank- }}{ }^{-}$ mKate2 cat (Stefanic et al., 2015), Escherichia coli MG1655 and Vibrio ruber DSM14379 (Stopar et al., 2004; Borić et al., 2011). In addition mutant strains of $B$. subtilis PS-216 $\Delta$ lytABC::neo,
B. subtilis PS-216 $\Delta$ lytABC::neo $\triangle$ lytD::tet, B. subtilis PS$216 \Delta$ lytABC::neo $\Delta$ lytD::tet $\Delta l y t$ :::cam, B. subtilis PS-216 $\Delta l y t A B C::$ neo $\Delta l y t D::$ tet $\Delta l y t E:: c a m \Delta l y t F:: s p c$ and $B$. subtilis PS-216 srfA-lacZ neo were prepared. The lyt mutants were constructed by transforming the B. subtilis PS-216 wt strain with the DNA isolated from B. subtilis L16611 and B. subtilis L16628 obtained from BGSC (Margot and Karamata, 1992). The srfAlacZ construct was made by transforming B. subtilis PS-216 wt strain with the DNA isolated from B. subtilis KTB308 (Bacon Schneider et al., 2002). Bacillus strains were grown at $37^{\circ} \mathrm{C}$ (except B. mycoides at $28^{\circ} \mathrm{C}$ ) and $200 \mathrm{rpm}$ in $\mathrm{LB}$ medium or CM medium (Albano et al., 1987) or at $28^{\circ} \mathrm{C}$ and $200 \mathrm{rpm}$ in PYE medium with 3\% (w/V) NaCl (Danevčič et al., 2005).

\section{Prodigiosin Extraction}

Vibrio ruber DSM14379 was cultured overnight in PYE medium with $3 \%(w / V) ~ N a C l$ at $28^{\circ} \mathrm{C}$ and $200 \mathrm{rpm}$ (Danevčič et al., 2005). Overnight culture was diluted 100 times in $400 \mathrm{~mL}$ of fresh M9 medium supplied with $5 \mathrm{~g} / \mathrm{L}$ glucose (Starič et al., 2010) and incubated for $16 \mathrm{~h}$ at the same growth conditions. Cells were harvested with centrifugation at $10397 \mathrm{~g}$ for $10 \mathrm{~min}$. Prodigiosin was extracted from cells with an equal volume of acetone at $28^{\circ} \mathrm{C}$ and $200 \mathrm{rpm}$ for $2 \mathrm{~h}$. After centrifugation for $15 \mathrm{~min}$ at $10397 \mathrm{~g}$ to remove cell debris, the solvent was evaporated. Dry biomass was resuspended in sterile $96 \%(\mathrm{~V} / \mathrm{V})$ ethanol and the pigment extract was filtered through $0.20 \mu \mathrm{m}$ filter. Prodigiosin concentration in the extract was determined as described previously by Starič et al. (2010). The prodigiosin purity in the extract was confirmed by HPLC using Kinetex C18 column $(250 \mathrm{~mm} \times 4.6 \mathrm{~mm}$, $5 \mu \mathrm{m}$, Phenomenex, USA) according to the modified method described previously (Nakashima et al., 2006). The separation was achieved using $0.1 \%$ trifluoroacetic acid (A) and methanol (B) mobile phases, and a gradient elution program at $1 \mathrm{~mL}^{-1} \mathrm{~min}$ with the following parameters: $0-5 \mathrm{~min} 100 \% \mathrm{~A}, 5-25 \mathrm{~min} \mathrm{0-}$ $100 \% \mathrm{~B}$ (linear gradient), 25-30 min 100\% B (isocratic), and 30-50 $\mathrm{min} 100 \% \mathrm{~A}$ (isocratic) to re-equilibrate the column, monitored by UV-VIS detection. The purity was determined by HPLC at different wavelengths in the range from 400 to $600 \mathrm{~nm}$. The HPLC elugram at $535 \mathrm{~nm}$ is given in supplementary materials (Supplementary Figure S1). In the tested range the extract contained more than $98 \%$ prodigiosin of both isomers $\alpha$ and $\beta$.

\section{Minimal Inhibitory Concentration Determination}

Minimal inhibitory concentration (MIC) values were determined in 96-well microtiter plate assay according to CLSI standards (Clinical and Laboratory Standards Institute, 2009). Briefly, bacterial strains were grown overnight in LB medium at $28^{\circ} \mathrm{C}$ or $37^{\circ} \mathrm{C}$. Inoculum was prepared by diluting overnight cultures in $0.9 \% \mathrm{NaCl}$ to $0.5 \mathrm{McFarland}\left(\sim 10^{7}\right.$ cells per $\left.\mathrm{mL}\right)$. Wells of microtiter plates were filled with $0.1 \mathrm{~mL}$ of the appropriate concentration of the prodigiosin, ethanol or water and $0.01 \mathrm{~mL}$ of the inoculum to have the approximate number of cells in each inoculated well $10^{5}$. The dilutions of prodigiosin, ethanol and water were made in LB medium. Prodigiosin was diluted in the final concentration range from $0.6 \mathrm{mg} \mathrm{L}^{-1}$ to $367.1 \mathrm{mg}$ 
$\mathrm{L}^{-1}$, while ethanol was diluted in the final concentration range from 0.02 to $12.03 \%(\mathrm{~V} / \mathrm{V})$. For positive controls LB medium was diluted with the same amounts of sterile distilled water as ethanol. Microtiter plates were incubated without shaking at $37^{\circ} \mathrm{C}$ for $20 \mathrm{~h}$ and the optical density at $650 \mathrm{~nm}\left(\mathrm{OD}_{650}\right)$ was measured spectrophotometrically at the beginning and the end of incubation. The lowest prodigiosin concentration in the well with no growth after $20 \mathrm{~h}$ of incubation, was taken as the MIC value.

\section{Co-culture Experiments}

Bacillus subtilis PS-216 wt was grown either in co-culture with V. ruber DSM14379 or in pure culture. For co-culture experiments, strains were separately grown in PYE medium with $3 \%$ (w/V) $\mathrm{NaCl}$ (V. ruber) or in LB medium (B. subtilis) until the stationary phase. Co-cultures were inoculated into PYE medium with 3\% (w/V) NaCl with V. ruber DSM14379: B. subtilis PS-216 in the ratio $1: 2(\mathrm{~V}: \mathrm{V})$, the overall inoculum being $1 \%(\mathrm{~V} / \mathrm{V})$. CFU was determined at the beginning and $20 \mathrm{~h}$ after incubation at $28^{\circ} \mathrm{C}$ and $200 \mathrm{rpm}$. CFU values were determined on PYE plates without $\mathrm{NaCl}$ (for B. subtilis PS-216 wt) and PYE plates with $3 \%(\mathrm{w} / \mathrm{V}) \mathrm{NaCl}$ (for both strains). Due to the red pigmentation of $V$. ruber DSM14379 the colonies were clearly distinguished. Malthusian fitness was calculated based on CFU counts according to Ahn et al. (2006). Prodigiosin concentration in co-cultures was determined as described previously in Borić et al. (2011).

\section{Cell Treatment with Prodigiosin in Different Growth Phases}

Bacillus subtilis PS-216 wt cells were cultured in liquid LB medium at $37^{\circ} \mathrm{C}$ and $200 \mathrm{rpm}$ overnight. Overnight culture was diluted 100 times in $20 \mathrm{~mL}$ of fresh LB medium and incubated further at the same growth conditions. $\mathrm{OD}_{650}$ was measured in regular intervals during the culture incubation. At appropriate $\mathrm{OD}_{650}$ in different growth phases [i.e., middle exponential $\left(\mathrm{OD}_{650} \sim 0.7\right)$, late exponential $\left(\mathrm{OD}_{650} \sim 1.1\right)$ and stationary phase $\mathrm{OD}_{650} \sim 1.3$ ], the strains were treated with $5.9 \mathrm{mg} \mathrm{L}^{-1}$ of prodigiosin. As a control, an equivalent amount of sterile $96 \%(\mathrm{~V} / \mathrm{V})$ ethanol was added to the LB medium in the final concentration $0.19 \%(\mathrm{~V} / \mathrm{V})$.

\section{Treatment of Different Bacterial Strains with Prodigiosin}

Bacillus mycoides DSM2048 cells were cultured in liquid LB medium at $28^{\circ} \mathrm{C}$ and $200 \mathrm{rpm}$ overnight, while B. licheniformis ATCC9445A cells were cultured in liquid LB medium at $37^{\circ} \mathrm{C}$ and $200 \mathrm{rpm}$ overnight. Overnight cultures were diluted 100 times in $20 \mathrm{~mL}$ of fresh LB medium and incubated further at the same growth conditions. Cultures were treated with prodigiosin (1.2 $\mathrm{mg} \mathrm{L}^{-1}$ B. mycoides or $6.9 \mathrm{mg} \mathrm{L}^{-1}$ B. licheniformis) or ethanol as a control $[0.04 \%(\mathrm{~V} / \mathrm{V})$ B. mycoides or 0.23 $\%(\mathrm{~V} / \mathrm{V})$ B. licheniformis] in the middle exponential phase at $\mathrm{OD}_{650}$ between 0.4 and 0.5 . Treated cells were then incubated further and $\mathrm{OD}_{650}$ was measured in regular intervals during $6 \mathrm{~h}$ of incubation. To determine the influence of prodigiosin on different strains, the rate of lysis was calculated from measured decrease of $\mathrm{OD}_{650}$ after prodigiosin treatment.

\section{Cell Morphology and Viability}

Bacillus subtilis PS-216 wt and B. subtilis PS-216 amyE:: $\mathrm{P}_{\text {hyperspank }}-m K a t e 2$ strains were grown in LB medium as described above and treated with $5.9 \mathrm{mg} \mathrm{L}^{-1}$ of prodigiosin or $0.19 \%(\mathrm{~V} / \mathrm{V})$ of ethanol in early exponential phase at $\mathrm{OD}_{650}$ between 0.4 and 0.5 . Cell morphology and viability were inspected by Differential Interference Contrast (DIC) and fluorescence microscopy using appropriate filter set under the inverted microscope Axio Observer Z1 (Carl Zeiss, Germany) at 0,1 , and $5 \mathrm{~h}$ after the prodigiosin or ethanol treatment.

\section{Effect of Prodigiosin on Inactive Cells}

Bacillus subtilis PS-216 wt cells were grown in LB medium as described above. When cells reached $\mathrm{OD}_{650}$ between 0.4 and 0.5 , bacterial culture was autoclaved at $121^{\circ} \mathrm{C}$ and 1.03 bar for $20 \mathrm{~min}$ to inactivate cells. After autoclaving, cell suspension was cooled down to room temperature and $5.9 \mathrm{mg} \mathrm{L}^{-1}$ of prodigiosin was added. Cell suspension was incubated further at $37^{\circ} \mathrm{C}$ and $200 \mathrm{rpm}$ and $\mathrm{OD}_{650}$ was measured every $30 \mathrm{~min}$ for $5 \mathrm{~h}$.

\section{Cytoplasmic Membrane Leakage}

Cytoplasmic membrane leakage was determined as $\beta$-galactosidase activity according to the modified method by Mensa et al. (2011). Briefly, B. subtilis PS-216 srfA-lacZ (neo) cells were grown overnight in LB medium with appropriate antibiotic at $37^{\circ} \mathrm{C}$ and $200 \mathrm{rpm}$ and diluted 100 times in $20 \mathrm{~mL}$ of the fresh $\mathrm{CM}$ medium. Cells were incubated at $37^{\circ} \mathrm{C}$ and $200 \mathrm{rpm}$ until they reach $\mathrm{OD}_{650} \sim 0.6$. At that point $70 \mu \mathrm{L}$ of cells were transferred in a microtiter plate and mixed with $20 \mu \mathrm{L}$ of $\mathrm{Z}$ buffer $\left(60 \mathrm{mM} \mathrm{Na}_{2} \mathrm{HPO}_{4}, 40 \mathrm{mM} \mathrm{NaH} \mathrm{PO}_{4}, 10 \mathrm{mM} \mathrm{KCl}\right.$, $10 \mathrm{mM} \mathrm{MgSO}_{4}, \mathrm{pH} 7$ ) supplemented with $4 \mathrm{mg} \mathrm{mL}^{-1} \mathrm{ONPG}$ (o-nitrophenyl- $\beta$-galactoside) and $40 \mu \mathrm{M} \beta$-mercaptoethanol. Cells were then treated with $10 \mu \mathrm{L}$ of prodigiosin to a final concentration of $2.9 \mathrm{mg} \mathrm{L}^{-1}$. Microtiter plates were incubated in a spectrometer for $2 \mathrm{~h}$ at $37^{\circ} \mathrm{C}$ and absorbance at $420 \mathrm{~nm}$ was measured every 2 min to determine the rate of ONPG hydrolysis. The addition of $10 \mu \mathrm{L}$ of $0.1 \%$ (w/V) sodium dodecyl sulfate (SDS) detergent [final concentration $0.01 \%(\mathrm{w} / \mathrm{V})$ ] represented a positive control, while the addition of $10 \mu \mathrm{L}$ of $96 \%(\mathrm{~V} / \mathrm{V})$ ethanol [final concentration $9.6 \%(\mathrm{~V} / \mathrm{V})$ ] represented a negative control. To calculate specific enzyme activity, the rate of ONPG hydrolysis was normalized to the cell biomass.

\section{Bacterial Response to Different Autolysin Inducing Agents}

Bacillus subtilis PS-216 wt strain was grown in LB medium as described above and treated with $0.0125 \%$ (V/V) Triton X100, 0.01\% (w/V) SDS , $0.01 \%$ (w/V) cetyl trimethylammonium bromide (CTAB), $100 \mu \mathrm{g} \mathrm{mL} \mathrm{m}^{-1}$ ampicillin or $100 \mu \mathrm{g} \mathrm{\textrm {mL } ^ { - 1 }}$ kanamycin in the middle exponential phase at $\mathrm{OD}_{650}$ between 0.4 and 0.5 . Ampicillin was used as a positive control known to induce cell lysis, whereas kanamycin was used as a negative control (Chung et al., 2009; Falk et al., 2010; Lacriola et al., 2013). 
Cell suspension was incubated further at $37^{\circ} \mathrm{C}$ and $200 \mathrm{rpm}$ and $\mathrm{OD}_{650}$ was measured every $30 \mathrm{~min}$ for $5 \mathrm{~h}$. To determine the impact of different detergents on bacterial strain, the rate of lysis was calculated from measured decrease of $\mathrm{OD}_{650}$ after treatment with antimicrobial agents.

\section{Autolytic Response of Bacterial Strains to Prodigiosin}

Bacillus subtilis strains PS-216 wt, PS-216 $\triangle$ lytABC, PS-216 $\triangle l y t A B C D$, PS-216 $\triangle l y t A B C D E$ and PS-216 $\triangle l y t A B C D E F$ were grown in LB medium as described above and treated with $5.9 \mathrm{mg}$ $\mathrm{L}^{-1}$ of prodigiosin or $0.19 \%(\mathrm{~V} / \mathrm{V})$ of ethanol as a negative control at $\mathrm{OD}_{650}$ between 0.4 and 0.7 . Cells were then incubated further and $\mathrm{OD}_{650}$ was measured in regular intervals during $6 \mathrm{~h}$ of incubation at $37^{\circ} \mathrm{C}$ and $200 \mathrm{rpm}$. To determine the influence of prodigiosin on different mutant strains, the rate of lysis was calculated from measured decrease of $\mathrm{OD}_{650}$ after prodigiosin treatment.

\section{Modified Comet Assay}

Bacillus subtilis strains PS-216 wt, PS-216 $\Delta l y t A B C$, PS-216 $\triangle l y t A B C D$, PS-216 $\triangle l y t A B C D E$ and PS-216 $\triangle l y t A B C D E F$ were grown in LB medium as described above. At $\mathrm{OD}_{650}$ between 0.4 and 0.6 cells were treated with $5.9 \mathrm{mg} \mathrm{L}^{-1}$ of prodigiosin or $0.19 \%$ $(\mathrm{V} / \mathrm{V})$ of ethanol. Cells were then incubated further for $1 \mathrm{~h}$ at $37^{\circ} \mathrm{C}$ and $200 \mathrm{rpm}$ to lyse. Minigels were prepared on frostedend microscopic slides. Slides were first dipped into $1 \%(\mathrm{w} / \mathrm{V})$ normal melting point agarose (NMP) and one side was wiped clean. After drying on a hot plate $\left(1 \mathrm{~min}, 100^{\circ} \mathrm{C}\right)$, the second layer of $300 \mu \mathrm{L} \mathrm{1 \%}$ (w/V) NMP agarose was applied and solidified at $4^{\circ} \mathrm{C}$ for $5 \mathrm{~min}$. For the third layer treated or non-treated cells were resuspended in $1 \%(\mathrm{w} / \mathrm{V})$ low melting agarose (ratio 1:10) and left to solidify for $5 \mathrm{~min}$. Minigels were immediately electrophoresed in TBE (Tris/borate/EDTA buffer, $\mathrm{pH}$ 8.3) at 1 $\mathrm{V} / \mathrm{cm}$ and run for $30 \mathrm{~min}$. Afterward minigels were neutralized in $400 \mathrm{mM}$ Tris buffer ( $\mathrm{pH} 7.4$ ). Gels were stained with 30x solution of GelRed ${ }^{\mathrm{TM}}$ (Biotium, USA) and observed under epifluorescent microscope (Olympus BX-50, Japan) equipped with EMCCD camera (Luca ${ }^{\mathrm{EM}}$ r, Andor Technology Ltd., United Kingdom) and the appropriate filter set. Images were captured by Komet 7.0 software (Andor Technology Ltd., UK).

\section{Data Analysis}

All the values presented are averages with standard deviations or standard errors. Results were statistically evaluated using oneway ANOVA. Samples with $p$-values equal or lower than 0.05 were taken as statistically significant.

\section{RESULTS AND DISCUSSION}

Prodigiosin isolated from V. ruber DSM14379 inhibits growth of different bacterial species. The MIC value for Escherichia coli is $103.4 \pm 6.3 \mathrm{mg} \mathrm{L}^{-1}$, while different Bacillus sp. strains tested have significantly lower MIC values. The MIC values for different Bacillus sp. strains were in the range between 5 and $7 \mathrm{mg} \mathrm{L}^{-1}$ (MIC values for B. amyloliquefaciens FZB42 was

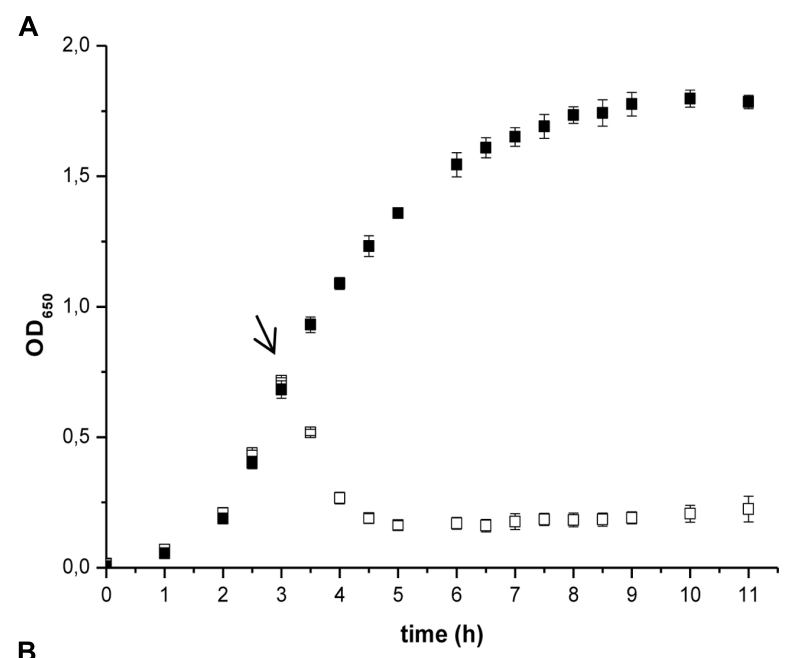

B

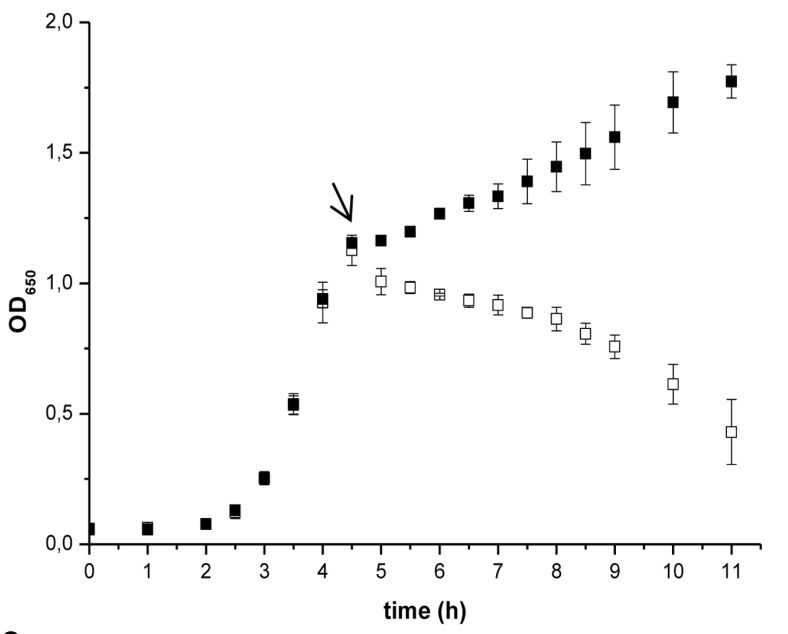

C

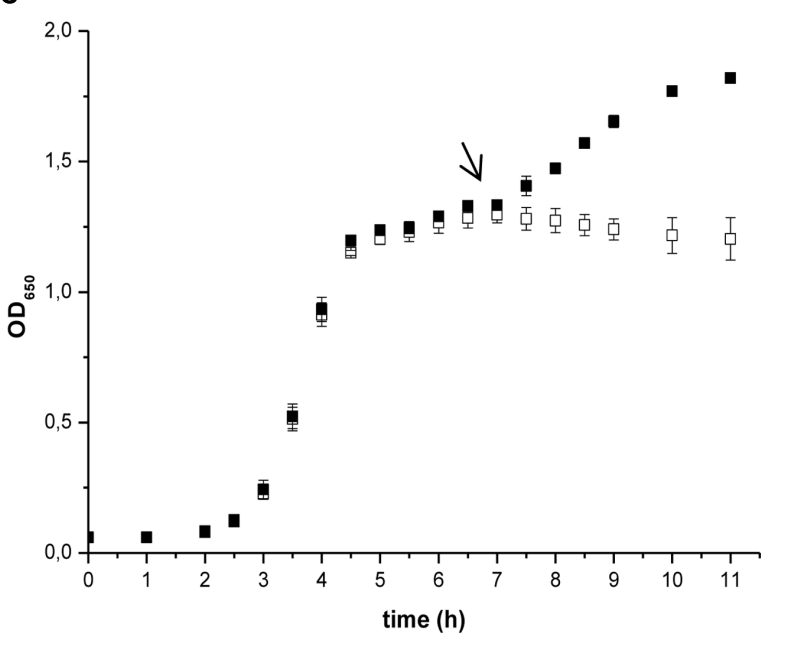

FIGURE 1 | The effect of prodigiosin addition on Bacillus subtilis PS-216 wt growth in LB medium at $37^{\circ} \mathrm{C}$ and $200 \mathrm{rpm}$ at different growth phases. The arrows represent the time of addition of $5.9 \mathrm{mg} \mathrm{L}^{-1}$ prodigiosin (opened squares) or $0.19 \%$ (VN) ethanol in the control samples (filled squares). (A) cells treated in the middle of the exponential phase; (B) cells treated in the late exponential phase; (C) cells treated in the stationary phase. Data are presented as averages and standard deviations $(n=3)$. 
A

$\mathbf{O h}$

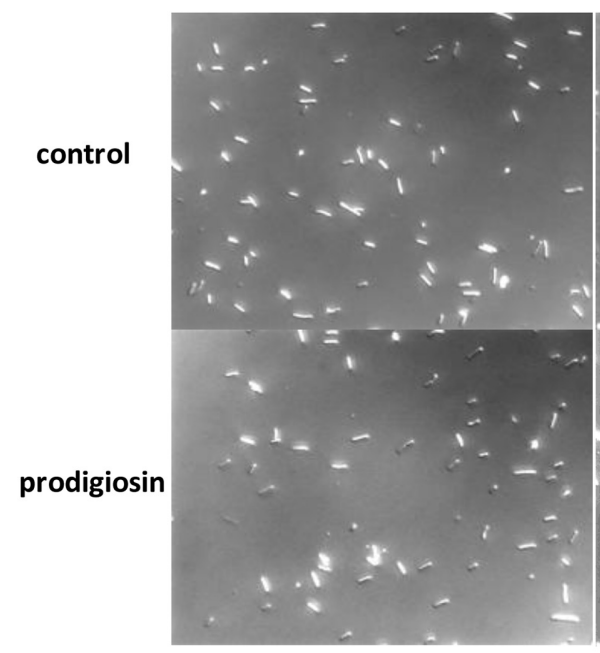

$1 \mathrm{~h}$

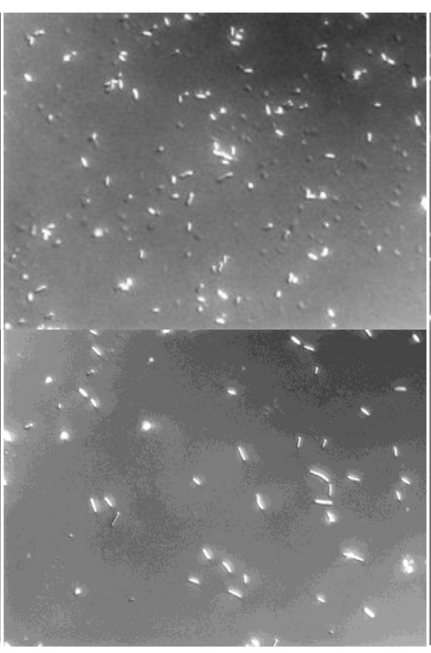

$5 h$

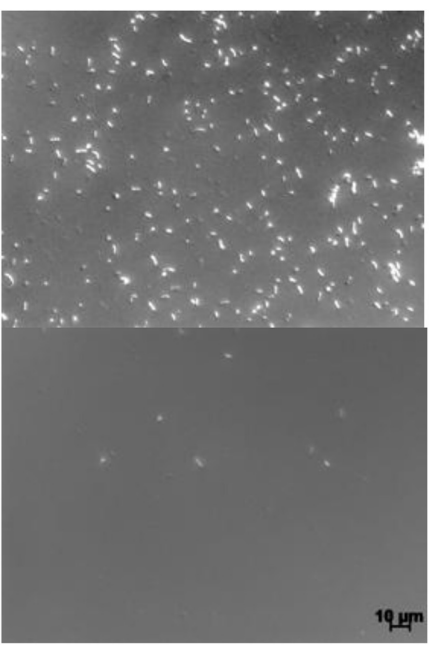

B

$\mathbf{O h}$

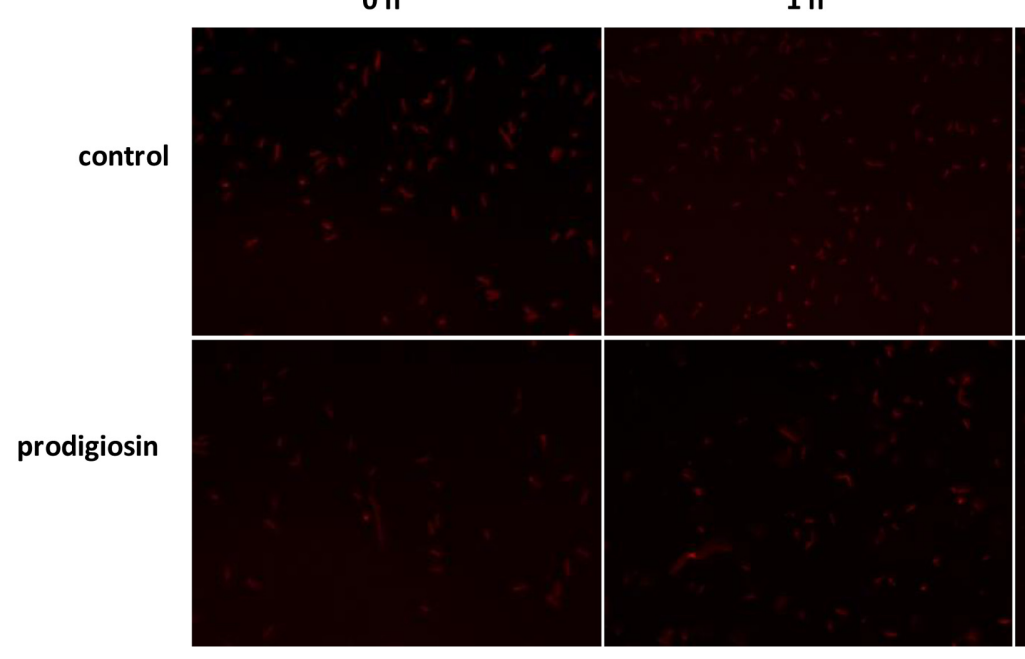

$5 \mathrm{~h}$

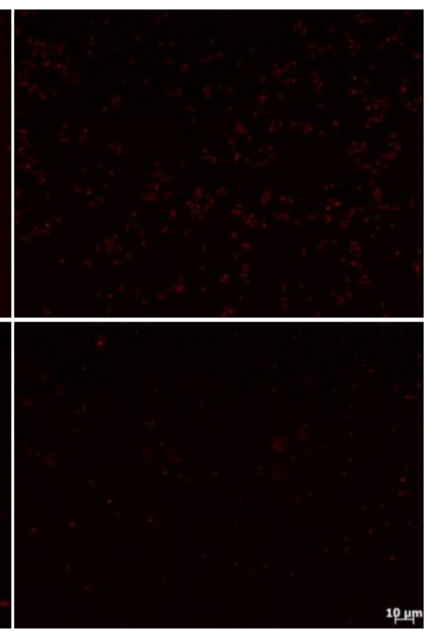

FIGURE 2 | Bacillus subtilis PS-216 wt cells (A) and B. subtilis PS-216 amyE::Phyerspank $-m K$ Kate2 (B) grown in LB medium at $37^{\circ} \mathrm{C}$ and $200 \mathrm{rpm}$ observed by DIC and fluorescent microscopy at 0,1 , and $5 \mathrm{~h}$ after the addition of either $5.9 \mathrm{mg} \mathrm{L}^{-1}$ of prodigiosin or $0.19 \%$ (V/V) of ethanol in control samples in the middle of the exponential phase. The scale bar represents $10 \mu \mathrm{m}$.

$6.1 \pm 1.2 \mathrm{mg} \mathrm{L}^{-1}$, B. licheniformis ATTC9445A was $6.9 \pm 2.2 \mathrm{mg}$ $\mathrm{L}^{-1}$, B. mycoides was $1.2 \mathrm{mg} \mathrm{L} \mathrm{L}^{-1}$, B. subtilis NCIB3610 was $5.2 \pm 1.4 \mathrm{mg} \mathrm{L}^{-1}$, B. subtilis ATCC6051 was $5.9 \mathrm{mg} \mathrm{L}^{-1}$ and B. subtilis PS-216 was $5.9 \mathrm{mg} \mathrm{L}^{-1}$ ) and were lower as previously reported (Stankovic et al., 2012; Priya et al., 2013). Approximately the same MIC values for different Bacillus species may suggest that prodigiosin has the same mode of action on all tested Bacillus sp. Only undomesticated natural isolate B. subtilis PS$216 w t$ was used for further analysis with MIC value $5.9 \mathrm{mg}$ $\mathrm{L}^{-1}$. To test the in vivo activity of prodigiosin on $B$. subtilis PS216 wt simple co-cultures with prodigiosin producing $V$. ruber DSM14379 were made. There was a significant decrease in the number of $B$. subtilis cells after incubation in co-culture. The
Malthusian fitness of $B$. subtilis grown in a monoculture was $5.7 \pm 0.2$, but was significantly lower $-6.8 \pm 1$ in co-culture experiments. The concentration of prodigiosin in co-culture at the end of the experiment was $16.3 \pm 0.4 \mathrm{mg} \mathrm{L}^{-1}$ which is 2.7 fold higher than the MIC required for growth inhibition of B. subtilis PS-216 wt. The results indicate that prodigiosin has in vivo antimicrobial activity.

The effect of prodigiosin on B. subtilis was dependent on the growth phase as shown in Figure 1. Prodigiosin treatment in the middle of the exponential phase (Figure 1A) caused instantaneous termination of growth and immediate decrease of optical density. Cell lysis was completed in $2 \mathrm{~h}$ after prodigiosin addition. As shown in Figure 2 cell number significantly 

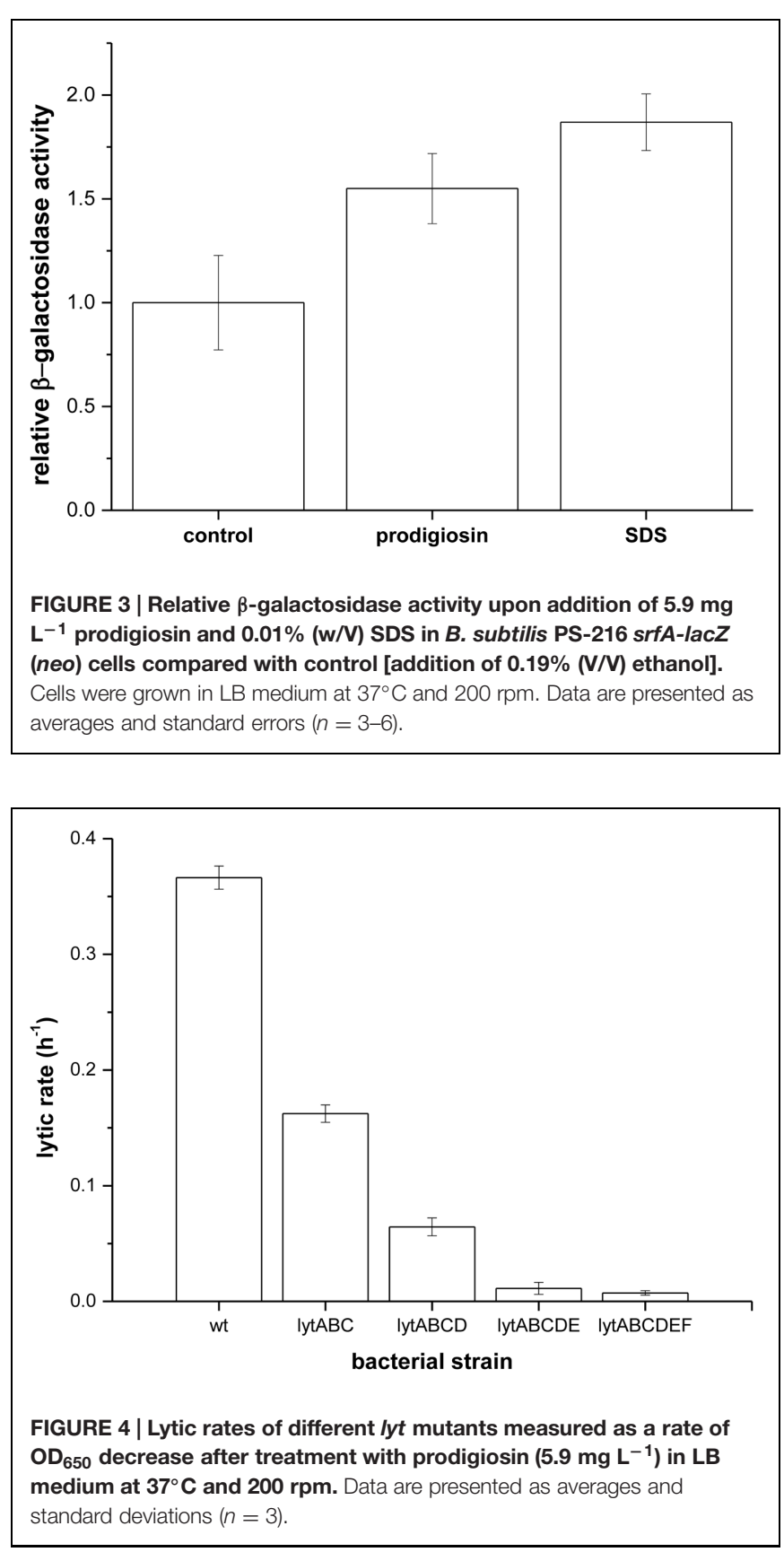

decreased after prodigiosin treatment. After $5 \mathrm{~h}$ of incubation with prodigiosin the bacterial solution was clear and only a few bacteria were observed. Cells treated with prodigiosin in the late exponential phase (Figure 1B) lysed as well. However, the rate of lysis was three times lower than in the middle of the exponential phase. After $5 \mathrm{~h}$ of prodigiosin treatment, optical density decreased for approximately $50 \%$. When cells were treated with prodigiosin in the stationary phase (Figure 1C) their growth ceased, but cells did not lyse. When those cells were re-inoculated into a fresh medium and incubated at optimal growth conditions, they resumed grow immediately. This implies that the mode of action of prodigiosin on B. subtilis cells depends on the growth phase. During the exponential growth prodigiosin has a bacteriolytic activity, whereas in the stationary phase it has bacteriostatic activity. This finding is not surprising, as it is generally accepted that effectiveness of antibiotic is greatly dependent on bacterial growth rate (Hobby et al., 1942; Greulich et al., 2015). For example, $\beta$-lactam antibiotics that target cell wall have their maximum effect during fast bacterial growth and are not effective toward stationary cells (Eng et al., 1991). The requirement of cell growth for prodigiosin susceptibilty was further tested with inactivated cells from the middle of the exponential phase. There was no significant change in optical density during $5 \mathrm{~h}$ of the incubation with prodigiosin, suggesting that the inactive cells did not lyse (data not shown). After the addition of the control containing ethanol (Figure 1), the growth of $B$. subtilis continued. Although the culture was not significantly diluted (the total volume increased only by $0.2 \%$ ), the added ethanol may have had a positive effect on the growth of B. subtilis as demonstrated previously (Gomaa, 2014).

For cell lysis one expects both cell wall and membrane disintegration. Prodigiosin is a small molecule that can diffuse through the cell wall and due to its amphiphilic character it can incorporate in the membrane (Diaz et al., 2007). Membrane loaded with prodigiosin may be compromised and allow leakage of cell constituents. To test cytoplasmic membrane permeability ONPG hydrolysis by $\beta$-galactosidase was used. ONPG can enter the cell and reach cytoplasmatic $\beta$-galactosidase only if cytoplasmic membrane is compromised. As given in Figure 3 prodigiosin was able to permeabilize cytoplasmic membrane. Similar permeabilization was observed with SDS detergent, which is a known cytoplasmic membrane solubilization agent in B. subtilis and Streptococcus faecalis (Bishop et al., 1967; Cornett and Shockman, 1978). There were no statistically significant differences between prodigiosin and SDS treatment $(p=0.4)$. The results indicate that prodigiosin interacts with cytoplasmic membrane and increases its permeability. Increased cytoplasmic permeability was associated with autolysis in B. subtilis (Falk et al., 2007). It has been shown that proton-motive force influences regulation of autolysins in B. subtilis cells (Calamita and Doyle, 2002). Prodigiosin functions in an energy-spilling process as a tightly regulated uncoupler of proton transport and ATP synthesis by oxidative phosphorylation (Haddix et al., 2008).

When cells were treated with prodigiosin in the middle of the exponential phase, approximately half of the cells lysed in $45 \mathrm{~min}$. This lytic rate of prodigiosin $\left(0.37 \pm 0.01 \mathrm{~h}^{-1}\right)$ is comparable to cell lysis induced by Triton X-100 $\left(0.36 \pm 0.03 \mathrm{~h}^{-1}\right)$ and ampicillin $\left(0.49 \pm 0.06 \mathrm{~h}^{-1}\right)$, which is a known autolysin induction agent (Lacriola et al., 2013). On the other hand, the other known agents that induce autolysins (i.e., SDS and CTAB) had lower lytic rates. SDS had lytic rate $0.13 \pm 0.01 \mathrm{~h}^{-1}$, while CTAB had lytic rate $0.15 \pm 0.01 \mathrm{~h}^{-1}$. Kanamycin known as a non-autolysin agent did not lyse $B$. subtilis, the lytic rate was $0.12 \pm 0.03 \mathrm{~h}^{-1}$. The results indicate that there was a significant difference between lytic rate of prodigiosin and SDS, which is different from the $\beta$-galactosidase results (Figure 3). Whereas $\beta$-galactosidase release assay shows the cytopasmic membrane permeabilisation, the lytic rate shows autolysin induction. The 


\section{A}
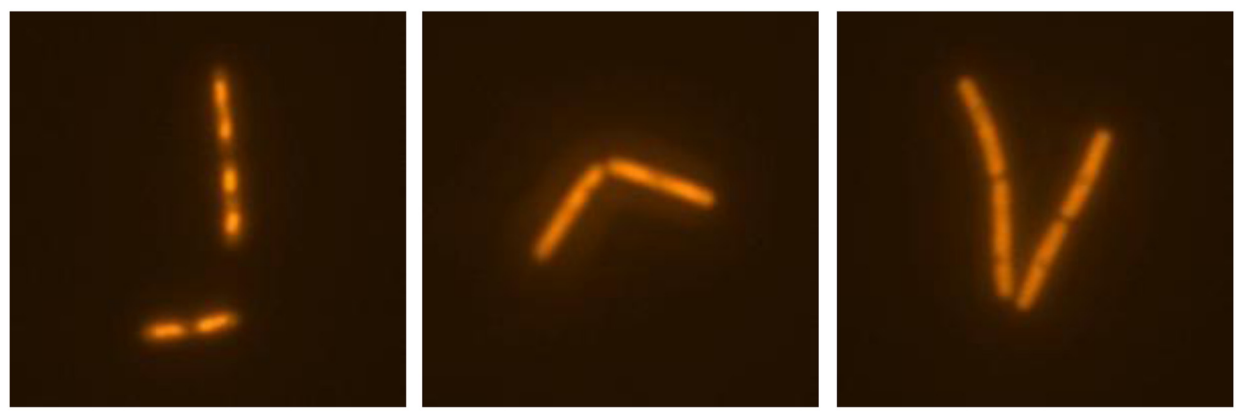

B
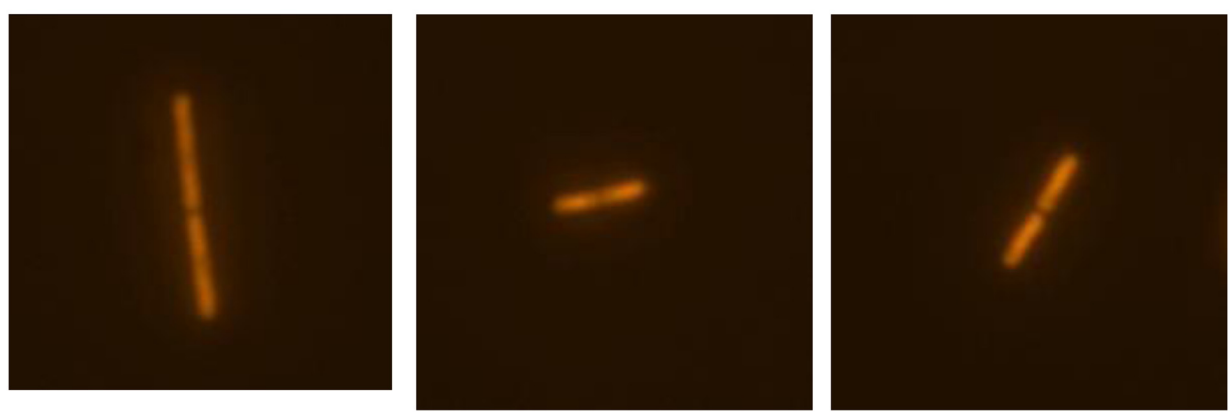

C
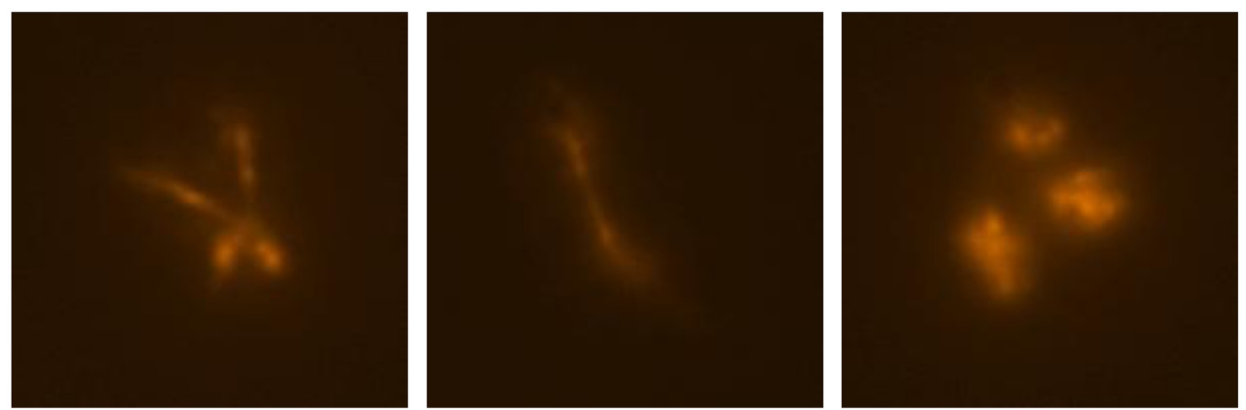

FIGURE 5 | The modified comet assay for studying prodigiosin mediated cell lysis of $B$. subtilis PS-216 wt cells grown in LB medium at $37^{\circ} \mathrm{C}$ and $200 \mathrm{rpm}$. (A) non-treated bacterial cells; (B) control cells treated with $0.19 \%$ (VN) of ethanol; (C) cells treated with $5.9 \mathrm{mg} \mathrm{L}^{-1}$ of prodigiosin. Cells were treated in the middle exponential phase and were inspected $1 \mathrm{~h}$ after the treatment. The gels were stained with GelRed ${ }^{\mathrm{TM}}$. The images were observed with epifluorescent microscopy.

two are not necessarily coupled. For example, SDS is a typical solubilizing agent of cytoplasmic membrane proteins in B. subtilis (Bishop et al., 1967), but is usually not used as an autolysin inducer due to its low lytic effectiveness. It has been demonstrated in Enterobacteriacea that the SDS-grown cells underwent rapid lysis only when they ran out of energy (Kramer et al., 1980). The energy dependence reflects a requirement for ATP rather than for a proton gradient or membrane potential (Aspedon and Nickerson, 1994). Prodigiosin, on the other hand, acts as a potent lytic agent for $B$. subtilis that uncouples proton transport in the cytoplasmic membrane (Haddix et al., 2008), thereby activating autolysins. Prodigiosin lytic activity was not limited to B. subtilis cells only. For example, treating B. mycoides and $B$. licheniformis with prodigiosin at MIC concentrations induces cell lysis and the cell suspension cleared after $20 \mathrm{~h}$ of treatment. The corresponding lytic rates were $0.014 \pm 0.002 \mathrm{~h}^{-1}$ for B. mycoides and $0.009 \pm 0.001 \mathrm{~h}^{-1}$ for B. licheniformis, which indicates that prodigiosin lytic activity could be a more general mechanism in Bacillus species.

To prove that prodigiosin induces autolysis several mutant strains of B. subtilis PS-216 deficient in major autolysis genes (lyt genes) were produced. The lytic rates after treatment with prodigiosin of mutant strains deficient to a different extent in autolytic response are given in Figure 4. In the lyt $A B C$ deficient strain the cell lysis was significantly reduced and the lytic rate was approximately two fold lower compared to the wild type strain. When additionally lytD gen was deleted a further decrease in the lytic rate was observed. The lyt $A B C D$ deficient strain 


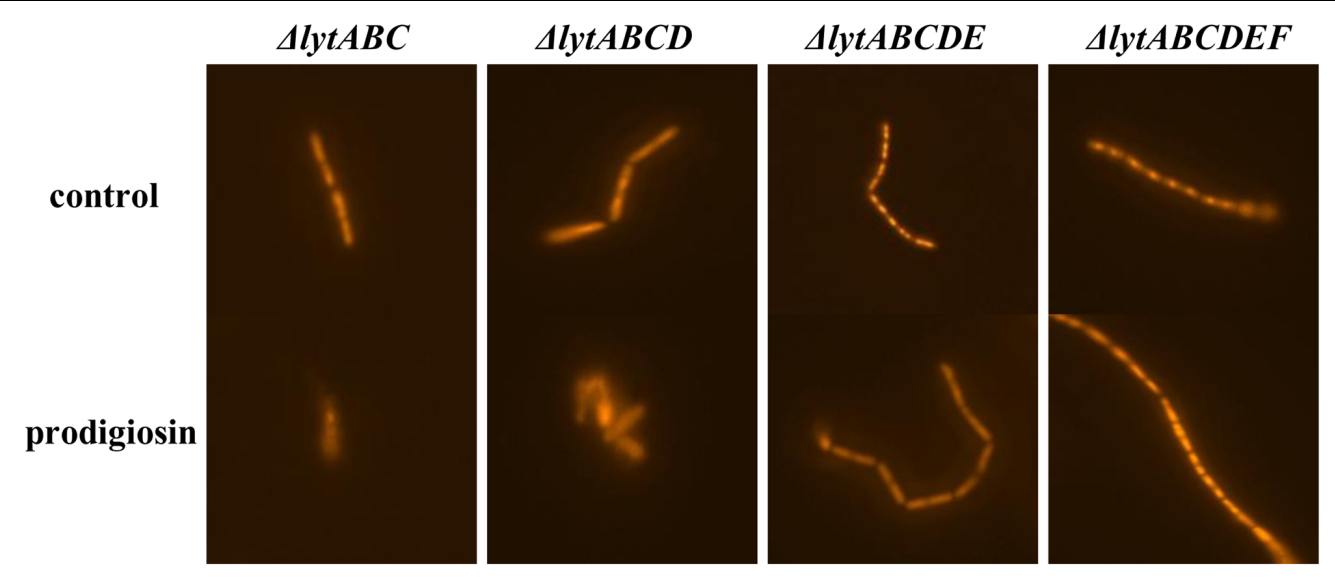

FIGURE 6 | The modified comet assay on different autolysin deficient strains of B. subtilis PS-216 cells grown in LB medium at $37^{\circ} \mathrm{C}$ and 200 rpm treated with $\mathbf{0 . 1 9} \%\left(\mathrm{~V} / \mathrm{V}\right.$ ) of ethanol (control) or treated with $5.9 \mathrm{mg} \mathrm{L}^{-1}$ of prodigiosin. Cells were treated in the middle exponential phase and were inspected $1 \mathrm{~h}$ after the treatment. The gels were stained with GelRed ${ }^{\mathrm{TM}}$. The images were observed with epifluorescent microscopy.

showed approximately $80 \%$ reduction of lysis compared to the wild type strain. This is consistent with previous reports of a key role of LytC and LytD in autolysis (Smith et al., 2000). In addition, it has been shown previously that $l y t E$ mutant may significantly reduce autolysis (Margot et al., 1998). Consistently in lyt $A B C D E$ mutant there was almost no lysis after prodigiosin addition. Finally, in lytABCDEF mutant the lytic rate upon addition of prodigiosin was 50 times lower compared to the wild type strain. Although no lytic response was observed in lytABCDEF mutant the addition of prodigiosin in the middle of exponential phase had a bacteriostatic effect. The results obtained by different lyt deficient strains strongly suggest that prodigiosin induces autolysin dependent bacteriolysis in B. subtilis. For a complete lysis of $B$. subtilis by prodigiosin a complement of different autolysins is needed. Since autolysins can be induced also by other amphiphatic molecules such as short- and mediumchain fatty acids (Tsuchido et al., 1985) this further supports the hypothesis that prodigiosin is a potent autolysin modulator.

The release of nucleic material during cell lysis was followed with modified comet assay (Figure 5). Non-treated cells retained cell integrity through the experiment, displaying clearly defined shape without tail or halo (Figure 5A). Similary, in control cultures treated with $0.19 \%(\mathrm{~V} / \mathrm{V})$ ethanol, the same concentration as used for prodigiosin solubilization, cells were intact (Figure 5B). On the other hand, treatment with prodigiosin induced instant lysis in almost all examined cells (Figure 5C). Cells that lysed appeared blurred with rapid decline of fluorescence indicating DNA diffusing out of disrupted cells. The comet assay was also applied to B. subtilis mutant strains deficient in major autolysin genes. Lyt mutants treated with prodigiosin responded differently. The comet assay suggests that lysis was most intense in lyt $A B C$ mutant. The degree of cell lysis decreased from lyt $A B C$ to lyt $A B C D E F$ deficient strain (Figure 6). Negligible cell lysis was observed in lytABCDEF mutant strain after prodigiosin treatment. The results obtained with the modified comet assay confirm that prodigiosin induces rapid autolysis in $B$. subtilis cells.
Finally, we note that upon entry into the stationary phase prodigiosin acts as a bacteriostatic agent. During transition to the stationary phase $B$. subtilis cells begin to lose their ability to move and start to produce biofilm. Biofilms and motility are mutually exclusive lifestyles of $B$. subtilis (Diethmaier et al., 2011) and are controlled by a common regulator, the transcription factor SinR. During biofilm formation SinR interacts with SinI and derepresses synthesis of extracellular matrix important in biofilm formation. One of the components of extracellular matrix EpsE interacts with flagellar motor switch protein FliG and prevents rotation of the flagellum (Blair et al., 2008). In addition, upon the entry into a stationary phase cells shut down synthesis of flagella components. The synthesis of flagella and autolysin are under the same regulation control. The synthesis of flagella proteins requires genes which are under the control of alternative RNA polymerase sigma factor, $\sigma^{\mathrm{D}}$ (Shahbabian et al., 2009). $\sigma^{\mathrm{D}}$ is a pleiotrophic transcription regulator during the exponential growth and has a positive effect on autolysin synthesis (Fein, 1979). Upon entry into the stationary phase $\sigma^{\mathrm{H}}$ decreases the expression of $\sigma^{\mathrm{D}}$ (Britton et al., 2002), which in turn downregulates autolysin production. In the absence of autolysins, as demonstrated in this work, the lytic activity of prodigiosin is abolished. However, as shown with lytABCDEF mutant prodigiosin may still act as a bacteriostatic agent preventing further growth of B. subtilis.

\section{CONCLUSION}

The application of prodigiosin as an antibacterial agent is hampered by the lack of knowledge of its molecular targets. The results of this study demonstrate that prodigiosin exhibits a potent antimicrobial activity against $B$. subtilis. It acts as a bacteriolytic agent during the exponential growth and as a bacteriostatic agent during the stationary growth. Prodigiosin interferes with cytoplasmic membrane function and increases its permeability. The obtained results indicate that prodigiosin's 
bacteriolytic activity is due to the induction of autolysins. Prodigiosin proves to be a strong autolysin inducer in B. subtilis cells comparable in its activity to Triton X-100. Since prodigiosin functions as an uncoupler of proton transport and ATP synthesis, it is ideally suited for autolysins induction and killing of different Bacillus species.

\section{AUTHOR CONTRIBUTIONS}

Conceived and designed the experiments: TD, MV, and DS. Performed the experiments: TD, MV, MT, and MZ. Analyzed the data: TD, MV, MT, and MZ. Wrote the paper: TD, MV and DS.

\section{REFERENCES}

Ahn, H. J., La, H. J., and Forney, L. J. (2006). System for determining the relative fitness of multiple bacterial populations without using selective markers. Appl. Environ. Microbiol. 72, 7383-7385. doi: 10.1128/AEM.01246-06

Albano, M., Hahn, J., and Dubnau, D. (1987). Expression of competence genes in Bacillus subtilis. J. Bacteriol. 169, 3110-3117.

Alihosseini, F., Ju, K. S., Lango, J., Hammock, B. D., and Sun, G. (2008). Antibacterial colorants: characterization of prodiginines and their applications on textile materials. Biotechnol. Prog. 24, 742-747. doi: 10.1021/bp070481r

Aspedon, A., and Nickerson, K. W. (1994). The energy dependence of detergent resistance in Enterobacter cloacae: a likely requirement for ATP rather than a proton gradient or a membrane potential. Can. J. Microbiol. 40, 184-191. doi: 10.1139/m94-031

Bacon Schneider, K., Palmer, T. M., and Grossman, A. D. (2002). Characterization of comQ and comX, two genes required for production of ComX pheromone in Bacillus subtilis. J. Bacteriol. 184, 410-419. doi: 10.1128/JB.184.2. 410-419.2002

Bishop, D. G., Rutberg, L., and Samulsson, B. (1967). The solubilization of the cytoplasmic membrane of Bacillus subtilis by sodium dodecyl sulphate. Eur. J. Biochem. 2, 454-459. doi: 10.1111/j.1432-1033.1967.tb00159.x

Blair, K. M., Turner, L., Winkelman, J. T., Berg, H. C., and Kearns, D. B. (2008). A molecular clutch disables flagella in the Bacillus subtilis biofilm. Science 320, 1636-1638. doi: 10.1126/science.1157877

Borić, M., Danevčič, T., and Stopar, D. (2011). Prodigiosin from Vibrio sp. DSM 14379; a new UV-protective pigment. Microb. Ecol. 62, 528-536. doi: 10.1007/s00248-011-9857-0

Britton, R. A., Eichenberger, P., Gonzalez-Pastor, J. E., Fawcett, P., Monson, R., Losick, R., et al. (2002). Genome-wide analysis of the stationary-phase sigma factor (sigma-H) regulon of Bacillus subtilis. J. Bacteriol. 184, 4881-4890. doi: 10.1128/JB.184.17.4881-4890

Burger, S. R., and Bennett, J. W. (1985). Droplet enrichment factors of pigmented and nonpigmented Serratia marcescens: possible selective function for prodigiosin. Appl. Environ. Microbiol. 50, 487-490.

Calamita, H. G., and Doyle, R. J. (2002). Regulation of autolysins in teichuronic acid-containing Bacillus subtilis cells. Mol. Microbiol. 44, 601-606. doi: 10.1046/j.1365-2958.2002.02872.x

Chung, J. K., Yoon, H. E., Shin, H. C., Choi, E. Y., and Byeon, W. H. (2009). Induction of growth phase-specific autolysis in Bacillus subtilis 168 by growth inhibitors. J. Microbiol. 47, 50-59. doi: 10.1007/s12275-008-0256-2

Clinical and Laboratory Standards Institute (2009). Methods for Dilution Antimicrobial Susceptibility Tests for Bacteria that Grow Aerobically; Approved Standard, 8th Edn. Wayne, PA: Clinical and Laboratory Standards Institute.

Cornett, J. B., and Shockman, G. D. (1978). Cellular lysis of Streptococcus faecalis induced with Triton X-100. J. Bacteriol. 135, 153-160.

Danevčič, T., Rilfors, L., Štrancar, J., Lindblom, G., and Stopar, D. (2005). Effects of lipid composition on the membrane activity and lipid phase behaviour of Vibrio sp. DSM14379 cells grown at various $\mathrm{NaCl}$ concentrations. Biochim. Biophys. Acta 1712, 1-8. doi: 10.1016/j.bbamem.2005.03.013

\section{ACKNOWLEDGMENTS}

We acknowledge financial support from the Slovenian Research Agency (ARRS no. 1000-09-310208). This work was also supported by the Slovenian Research Agency grant P4-0116. We are thankful to Polonca Stefanic for providing B. subtilis PS-216 $w t$ and PS-216 srfA-lacZ (neo) strains.

\section{SUPPLEMENTARY MATERIAL}

The Supplementary Material for this article can be found online at: http://journal.frontiersin.org/article/10.3389/fmicb. 2016.00027

Diaz, R. I. S., Regourd, J., Santacroce, P. V., Davis, J. T., Jakeman, D. L., and Thompson, A. (2007). Chloride anion transport and copper - mediated DNA cleavage by C-ring functionalized prodigiosenes. Chem. Commun. 26, 27012703. doi: 10.1039/B701919J

Diethmaier, C., Pietack, N., Gunka, K., Wrede, C., Lehnik-Habrink, M., Herzberg, C., et al. (2011). A novel factor controlling bistability in Bacillus subtilis: the YmdB protein affects flagellin expression and biofilm formation. J. Bacteriol. 193, 5997-6007. doi: 10.1128/JB.05360-11

Eng, R. H., Padberg, F. T., Smith, S. M., Tan, E. N., and Cherubin, C. E. (1991). Bactericidal effects of antibiotics on slowly growing and nongrowing bacteria. Antimicrob. Agents Chemother. 35, 1824-1828. doi: 10.1128/AAC.35. 9.1824

Falk, S. P., Noah, J. W., and Weisblum, B. (2010). Screen for inducers of autolysis in Bacillus subtilis. Antimicrob. Agents Chemother. 54, 3723-3729. doi: 10.1128/AAC.01597-09

Falk, S. P., Ulijasz, A. T., and Weisblum, B. (2007). Differential assay for high-throughput screening of antibacterial compounds. J. Biomol. Screen. 12, 1102-1108. doi: 10.1177/1087057107308161

Farmer, J. J., Hickman-Brenner, F. W., Fanning, G. R., Gordon, C. M., and Brenner, D. J. (1988). Characterization of Vibrio metschnikovii and Vibrio gazogenes by DNA-DNA hybridization and phenotype. J. Clin. Microbiol. 26, 1993-2000.

Fehér, D., Barlow, R. S., Lorenzo, P. S., and Hemscheidt, T. K. (2010). A 2-Substituted Prodiginine, 2-(p-Hydroxybenzyl)prodigiosin, from Pseudoalteromonas rubra. J. Nat. Prod. 71, 1970-1972. doi: 10.1021/np800493p

Fein, J. E. (1979). Possible involvement of bacterial autolytic enzymes in flagellar morphogenesis. J. Bacteriol. 137, 933-946.

Gomaa, E. Z. (2014). Production of polyhydroxyalkanoates (PHAs) by Bacillus subtilis and Escherichia coli grown on cane molasses fortified with ethanol. Braz. Arch. Biol. Technol. 57, 145-154. doi: 10.1590/S1516-89132014000100020

Greulich, P., Scott, M., Evans, M. R., and Allen, R. J. (2015). Growth - dependent bacterial susceptibility to ribosome - targeting antibiotics. Mol. Syst. Biol. 11, 796. doi: 10.15252/msb.20145949

Guryanov, I. D., Karamova, N. S., Yusupova, D. V., Gnezdilov, O. I., and Koshkarova, L. A. (2013). Bacterial pigment prodigiosin and its genotoxic effect. Russ. J. Bioorg. Chem. 39, 106-111. doi: 10.1134/S1068162012060040

Haddix, P. L., Jones, S., Patel, P., Burnham, S., Knights, K., Powell, J. N., et al. (2008). Kinetic analysis of growth rate, ATP, and pigmentation suggests an energy-spilling function for the pigment prodigiosin of Serratia marcescens. J. Bacteriol. 190, 7453-7463. doi: 10.1128/JB.00909-08

Hobby, G. L., Meyer, K., and Chaffee, E. (1942). Observation on the mechanism of penicillin. Proc. Soc. Exp. Biol. Med. 50, 281-285. doi: 10.3181/00379727-5013773

Hood, D. W., Heidstra, R., Swoboda, U. K., and Hodgson, D. A. (1992). Molecular genetic analysis of proline and tryptophan biosynthesis in Streptomyces coelicolor A3(2): interaction between primary and secondary metabolism - a review. Gene 115, 5-12. doi: 10.1016/0378-1119(92)90533-U

Jolliffe, L. K., Doyle, R. J., and Streips, U. N. (1981). The energized membrane and cellular autolysis in Bacillus subtilis. Cell 25, 753-763. doi: 10.1016/00928674(81)90183-5 
Kemper, M. A., Urrutia, M. M., Beveridge, T. J., Koch, A. L., and Doyle, R. J. (1993). Proton motive force may regulate cell wall-associated enzymes of Bacillus subtilis. J. Bacteriol. 175, 5690-5696.

Khairnar, K., Sanmukh, S., Chandekar, R., and Paunikar, W. (2014). A simple and novel modification of comet assay for determination of bacteriophage mediated bacterial cell lysis. J. Virol. Methods 203, 33-38. doi: 10.1016/j.jviromet.2014.02.028

Konno, H., Matsuya, H., Okamoto, M., Sato, T., Tanaka, Y., Yokoyama, K., et al. (1998). Prodigiosins uncouple mitochondrial and bacterial F-ATPases: evidence for their $\mathrm{H}+/ \mathrm{Cl}-$ symport activity. J. Biochem. 124, 547-556. doi: 10.1093/oxfordjournals.jbchem.a022147

Kramer, V. C., Calabrese, D. M., and Nickerson, K. W. (1980). Growth of Enterobacter cloacae in the presence of $25 \%$ sodium dodecyl sulfate. Appl. Environ. Microbiol. 40, 973-976.

Kumar, N. R., and Nair, S. (2007). Vibrio rhizosphaerae sp. nov.; a redpigmented bacterium that antagonizes phytopathogenic bacteria. Int. J. Syst. Evol. Microbiol. 57, 2241-2246. doi: 10.1099/ijs.0.65017-0

Lacriola, C. J., Falk, S. P., and Weisblum, B. (2013). Screen for agents that induce autolysis in Bacillus subtilis. Antimicrob. Agents Chemother. 57, 229-234. doi: 10.1128/AAC.00741-12

Lee, J. S., Kim, Y. S., Park, S., Kim, J., Kang, S. J., Lee, M. H., et al. (2011). Exceptional production of both prodigiosin and cycloprodigiosin as major metabolic constituents by a novel marine bacterium, Zooshikella rubidus S1-1. Appl. Environ. Microbiol. 77, 4967-4973. doi: 10.1128/AEM.01986-10

Margot, P., and Karamata, D. (1992). Identification of the structural genes for N-acetylmuramoyl-L-alanine amidase and its modifier in Bacillus subtilis 168: inactivation of these genes by insertional mutagenesis has no effect on growth or cell separation. Mol. Gen. Genet. 232, 359-366. doi: 10.1007/BF002 66238

Margot, P., Whalen, M., Ghdamhoseinian, A., Piggot, P., and Karamata, D. (1998). The lytE gene of Bacillus subtilis 168 encodes a cell wall hydrolase. J. Bacteriol. 180, 749-752.

Melvin, M. S., Tomlinson, J. T., Saluta, G. R., Kucera, G. L., Lindquist, N., and Manderville, R. A. (2000). Double-strand DNA cleavage by copper-prodigiosin. J. Am. Chem. Soc. 122, 6333-6334. doi: 10.1021/ja0000798

Mensa, B., Kim, Y. H., Choi, S., Scott, R., Caputo, G. A., and DeGrado, W. F. (2011). Antibacterial mechanism of action of arylamide foldamers. Antimicrob. Agents Chemother. 55, 5043-5053. doi: 10.1128/AAC.05009-11

Meschke, H., Walter, S., and Schrempf, H. (2012). Characterization and localization of prodiginines from Streptomyces lividans suppressing Verticillium dahliae in the absence or presence of Arabidopsis thaliana. Environ. Microbiol. 14, 940-952. doi: 10.1111/j.1462-2920.2011.02665.x

Nakashima, T., Miyazaki, Y., Matsuyama, Y., Muraoka, W., Yamaguchi, K., and Oda, T. (2006). Producing mechanism of an algicidal compound against red tide phytoplankton in a marine bacterium $\gamma$-proteobacterium. Appl. Microbiol. Biotechnol. 73, 684-690. doi: 10.1007/s00253-006-0507-2

Okamoto, H., Sato, Z., Sato, M., Koiso, Y., Iwasaki, S., and Isaka, M. (1998). Identification of antibiotic red pigments of Serratia marcescens F-1-1, a biocontrol agent of damping-off of cucumber, and antimicrobial activity against other plant pathogens. Ann. Phytopathol. Soc. Jpn. 64, 294-298. doi: 10.3186/jjphytopath.64.294

Ostling, O., and Johanson, K. J. (1984). Microelectrophoretic study of radiationinduced DNA damages in individual mammalian cells. Biochem. Biophys. Res. Commun. 123, 291-298. doi: 10.1016/0006-291X(84)90411-X

Pérez-Tomás, R., Montaner, B., Llagostera, E., and Soto-Cerrato, V. (2003). The prodigiosins, proapoptotic drugs with anticancer properties. Biochem. Pharmacol. 66, 1447-1452. doi: 10.1016/S0006-2952(03)00496-9

Priya, K. A., Satheesh, S., Ashokkumar, B., Varalakshmi, P., Selvakumar, G., and Sivakumar, N. (2013). "Antifouling activity of prodigiosin from estuarine isolate of Serratia marcescens CMST 07," in Microbiological Research in Agroecosystem Management, Vol. XVI, ed. R. K. Velu (New Delhi: Springer), 11-21. doi: 10.1007/978-81-322-1087-0_2

Ryazantseva, I. N., Andreyeva, I. N., Klementyeva, G. S., Ogorodnikova, T. I., and Petrov, V. Y. (1995). Pigment-dependent light influence on the energetics of Serratia marcescens. Thermochim. Acta 251, 63-67. doi: 10.1016/00406031(94)02148-H

Sawabe, T., Makino, H., Tatsumi, M., Nakano, K., Tajima, K., Iqbal, M. M., et al. (1998). Pseudoalteromonas bacteriolytica sp. nov.; a marine bacterium that is the causative agent of red spot disease of Laminaria japonica. Int. J. Syst. Bacteriol. 48, 769-774. doi: 10.1099/00207713-48-3-769

Seganish, J. L., and Davis, J. T. (2005). Prodigiosin is a chloride carrier that can function as an anion exchanger. Chem. Commun. 46, 5781-5783. doi: 10.1039/B511847F

Shahbabian, K., Jamalli, A., Zig, L., and Putzer, H. (2009). Rnase Y, a novel endoribonuclease, initiates riboswitch turnover in Bacillus subtilis. EMBO J. 28, 3523-3533. doi: 10.1038/emboj.2009.283

Shieh, W. Y., Chen, Y. W., Chaw, S. M., and Chiu, H. H. (2003). Vibrio ruber sp. nov.; a red, facultatively anaerobic, marine bacterium isolated from sea water. Int. J. Syst. Evol. Microbiol. 53, 479-484. doi: 10.1099/ijs.0. 02307-0

Singh, N. P., McCoy, M. T., Tice, R. R., and Schneider, E. L. (1988). A simple technique for quantification of low levels of DNA damage in individual cells. Exp. Cell Res. 175, 184-191. doi: 10.1016/0014-4827(88) 90265-0

Smith, T. J., Blackman, S. A., and Foster, S. J. (2000). Autolysis of Bacillus subtilis: multiple enzymes with multiple functions. Microbiology 146, 249-262. doi: 10.1099/00221287-146-2-249

Someya, N., Nakajima, M., Hirayae, K., Hibi, T., and Akutsu, K. (2001). Synergistic antifungal activity of chitinolytic enzymes and prodigiosin produces by biocontrol bacterium, Serratia marcescens strain B2 against gray mold pathogen, Botrytis cinerea. J. Gen. Plant Pathol. 67, 312-317. doi: 10.1007/PL00013038

Stankovic, N., Radulovic, V., Petkovic, M., Vuckovic, I., Jadranin, M., Vasiljevic, B., et al. (2012). Streptomyces sp. JS520 produces exceptionally high quantities of undecylprodigiosin with antibacterial, antioxidative, and UV-protective properties. Appl. Microbiol. Biotechnol. 96, 1217-1231. doi: 10.1007/s00253012-4237-3

Stankovic, N., Senerovic, L., Ilic-Tomic, T., Vasiljevic, B., and Nikodinovic-Runic, J. (2014). Properties and applications of undecylprodigiosin and other bacterial prodigiosins. Appl. Microbiol. Biotechnol. 98, 3841-3858. doi: 10.1007/s00253014-5590-1

Starič, N., Danevčič, T., and Stopar, D. (2010). Vibrio sp. DSM14379 pigment production - a competitive advantage in the environment? Microb. Ecol. 60, 592-598. doi: 10.1007/s00248-010-9671-0

Stefanic, P., Kraigher, B., Lyons, N. A., Kolter, R., and Mandic-Mulec, I. (2015). Kin discrimination between sympatric Bacillus subtilis isolates. Proc. Natl. Acad. Sci. U.S.A. 112, 14042-14047. doi: 10.1073/pnas.1512671112

Stefanic, P., and Mandic-Mulec, I. (2009). Social interactions and distribution of Bacillus subtilis pherotypes at microscale. J. Bacteriol. 191, 1756-1764. doi: 10.1128/JB.01290-08

Stopar, D., Cerne, A., Zigman, M., Poljsak-Prijatelj, M., and Turk, V. (2004). Viral abundance and a high proportion of lysogens suggest that viruses are important members of the microbial community in the Gulf of Trieste. Microb. Ecol. 47, 1-8. doi: 10.1007/s00248-002-3009-5

Tsuchido, T., Hiraoka, T., Takano, M., and Shibasaki, I. (1985). Involvement of autolysin in Bacillus subtilis induced by short- and medium-chain fatty acids. J. Bacteriol. 162, 42-46.

Williamson, N. R., Fineran, P. C., Gristwood, T., Chawrai, S. R., Leeper, F. J., and Salmond, G. P. C. (2006). The biosynthesis and regulation of bacterial prodiginines. Nat. Rev. Microbiol. 4, 887-899. doi: 10.1038/nrmicro1531

Williamson, N. R., Fineran, P. C., Gristwood, T., Chawrai, S. R., Leeper, F. J., and Salmond, G. P. C. (2007). Anticancer and immunosuppressive properties of bacterial prodiginines. Future Microbiol. 2, 605-618. doi: 10.2217/17460913.2.6.605

Conflict of Interest Statement: The authors declare that the research was conducted in the absence of any commercial or financial relationships that could be construed as a potential conflict of interest.

Copyright (c) 2016 Danevčič, Borić Vezjak, Tabor, Zorec and Stopar. This is an open-access article distributed under the terms of the Creative Commons Attribution License (CC BY). The use, distribution or reproduction in other forums is permitted, provided the original author(s) or licensor are credited and that the original publication in this journal is cited, in accordance with accepted academic practice. No use, distribution or reproduction is permitted which does not comply with these terms. 